\title{
STUDIES ON CHEMOTHERAPEUTIC DRUGS AGAINST VIRUSES
}

\author{
V. CHEMOTHERAPEUTIC EFFEGT OF SODIUM \\ 3-PHENYLAZONAPHTHIONATE ON \\ NEUROTROPIC VIRUS
TAKEO UEDA*, SHIGESHI TOYOSHIMA, TSUNEO WACHI, MITSUHARU TANIGUCHI and HIROSHI TATSUMI
The Pharmaceutical Institute, School of Medicine, Keio University

These studied were prompted by our observations ${ }^{(1)}$ according to which the diazo dyestuff sodium 3-phenylazonaphthionate exerted the strongest effect on the Japanese encephalitis virus in vitro among series of 3-phenylazonaphthionates. In these studies sodium 3-phenylazonaphthionate was investigated, in detail, as to its toxity, its antiviral activity in vitro and in vivo, and other pharmacological properties for its clinical application. This communication describes the chemotherapeutic properties of sodium 3-phenylazonaphthionate which is of promise for the clinical administration.

The compound is a substance of reddish yellow color, 'which was syntherized by us. It is soluble in water, but sparingly soluble in organic solvents. Its aqueous solution is so stable that its sterilization may be accomplished in various ways.

\section{MATERIALS AND METHODS}

The aqueous solution of sodium 3-phenylazonaphthionate was employed, dilutions of which were prepared to contain a desired amount of drug in $0,5 \mathrm{ml}$ with distilled water. For tests young mice of 10-12 $\mathrm{g}$ in weight were employed: each received the diluted virus. Solutions of drug were administered.

The Nakayama strain of Encephalitis japonica was employed, which was kindly given to us by Dr. K. Ando, Division of Bacteriology, National Institute of Health, Tokyo.

\section{EXPERIMENTAL PROGEDURES}

Experimental procedures were the same as described by S. D. Kramer et al ${ }^{(2)}$, W. C. Cutting et $\mathrm{al}^{(3)}$ H. G. Wood et $\mathrm{al}^{(4)}$ so on.

\footnotetext{
* Professor and Chief of the Pharmaceutical Institute.
} 
The strain was passed through mice by intracerebral infection and infected brains were prepared for these experiments and kept in the frozen state. Mice with the symptoms of the severe encephlitis were sacrified, brains removed, weighed and emulsified with serum and saline. The desired dilutions were prepared by adding $1.0 \mathrm{ml}$ amounts of the suspension to mixtures of serum and saline. The virulence of the virus was determined by titration. The virulence was consistent and did not change appreciably during the time of our experiments.

For the experiments, groups of 10-20 mice were inoculated with $0.2 \mathrm{ml}$ of diluted brain suspension. At intervals before or after the inoculation of the virus, mice received a single or more injections of the drug in $0.5 \mathrm{ml}$ per $10 \mathrm{~g}$. Treated and untreated mice were observed to their death or in case of suvival for 14 days and symptoms of infection were daily recorded. As a rule the first symptoms appeared 3 to 5 days after the inoculation and death occured within the first 8-10 days. After that time no essential changes were observed during the rest of the period.

\section{RESULTS}

1) Virucidal Effect in vitro. Mixtures of infective brain suspension ( $L D_{60}, 10^{-9.5}$ ) in concentrations ranging from $10^{-2.5}$ to $10^{-6.5}$ were prepared in $0.3-0.0375 \%$ solution of the drug and inoculated intracerebrally into groups of ten mice, immediately following the mixing or after $1-4$ hours at $23^{\circ} \mathrm{C}$. The results are given in the Table I by survival rate $(\%)$.

, Survival rates, following the exposure, of $70-100 \%$ were observed with these $10^{-6.5}-10^{-3.5}$ virus dilutions in $0.3 \%$ concentration of the drug, while the

Table 1. Virucidal Effect of the Drug in vitro

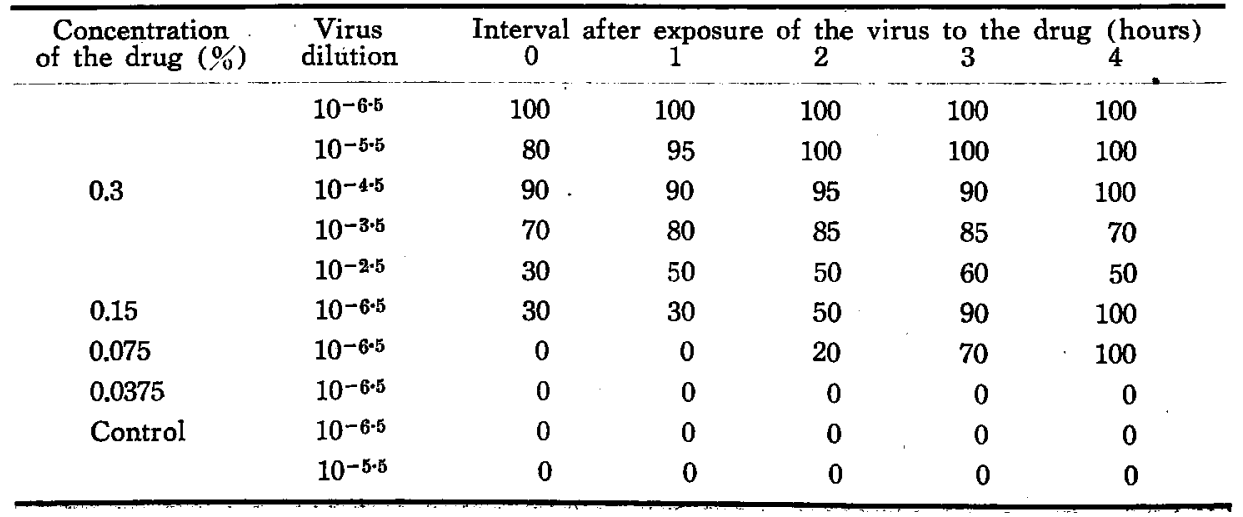


virus dilution of $10^{-9.5}$ represented $\mathrm{LD}_{50}$ of the virus. It is shown that the drug exerted a marked virucidal effect on the virus in vitro in concentration of more than $0.075 \%$, at intervals ( $0-4$ hours) after direct exposure of the virus.

2) Experimental Toxity. The toxic effect of a single injection of the compound sodium 3-phenylazonaphthionate was determined in mice. Each amount of $2.0,1.0,0.5,0.25,0.20,0.16$ and $0.125 \mathrm{~g}$ per $\mathrm{kg}$ was dissolved in $0.2 \mathrm{ml}$ distilled water, and injected intravenously into mice of about $13 \mathrm{~g}$ weight. The results are given in the Table 2 by survival ratio.

It may be determined from the Table that the maximal tolerative dose corresponded to $200 \mathrm{mg} / \mathrm{kg}$ for intravenous injection, and $250 \mathrm{mg} / \mathrm{kg}$ for the intraperitoneal route.

Table 2. Toxity of the Drug

\begin{tabular}{lccccccc} 
& & \multicolumn{4}{c}{ Dose of the Drug (g/kg) } \\
\hline Route of Administration & 2 & 1 & 0.5 & 0.25 & 0.2 & 0.16 & 0.125 \\
Intravenous & Dead & Dead & Dead & $0 / 4$ & $5 / 5$ & $5 / 5$ & $5 / 5$ \\
Intraperitoneal & - & Dead & Dead & $6 / 6$ & - & - & - \\
\hline
\end{tabular}

The numerator represents the member of mice that survived, the denominator the total number injected.

3) Protective Effect against Virus. Solutions of the drug were injected into groups of 20 mice by intraperitoneal route, with the dose of $150 \mathrm{mg} / \mathrm{kg}$ in addition of hyaluronidase of $0.1 \mathrm{unit} / \mathrm{kg}$, once daily for 4 days consecutively. And after that, dilutions of the virus were inoculated intranasally or intravenously into the mice. The results are given in the Table 3 and 4 by survival rate $(\%)$.

It is evident from these Tables that with infective doses of $10^{-4}-10^{-2}$ dilutions of the virus marked survival rates were observed with the 4 successive doses of $150 \mathrm{mg} / \mathrm{kg}$ each. It is, therefore, shown that the drug possessed a protective effect on the virus.

Table 3. Protective Effect of the Drug (1)

\begin{tabular}{|c|c|c|c|c|c|}
\hline \multicolumn{3}{|c|}{ Intranasal Infection } & \multicolumn{3}{|c|}{ Intravenous Infection } \\
\hline $\begin{array}{l}\text { Virus } \\
\text { dilution }\end{array}$ & $\begin{array}{l}\text { Control mice } \\
\text { Survival rate(\%) }\end{array}$ & $\begin{array}{c}\text { Treated mice } \\
\text { Survival rate(\%) }\end{array}$ & $\begin{array}{l}\text { Virus } \\
\text { dilution }\end{array}$ & $\begin{array}{l}\text { Control mice } \\
\text { Survival rate(\%) }\end{array}$ & $\begin{array}{l}\text { Treated mice } \\
\text { Survival rate }(\%)\end{array}$ \\
\hline $10^{-2}$ & 0 & 0 & $10^{-2}$ & 17 & 54 \\
\hline $10^{-3}$ & 17 & 30 & $10^{-3}$ & 33 & 70 \\
\hline $10^{-4}$ & 25 & 50 & $10^{-4}$ & 60 & 80 \\
\hline
\end{tabular}


Table 4. Protective Effect of the Drug (2)

\begin{tabular}{|c|c|c|c|c|c|}
\hline \multicolumn{3}{|c|}{ Intranasal Infection } & \multicolumn{3}{|c|}{ Intravenous Infection } \\
\hline $\begin{array}{l}\text { Virus } \\
\text { dilution }\end{array}$ & $\begin{array}{l}\text { Control mice } \\
\text { Survival rate( }\left({ }^{\prime}, 1\right)\end{array}$ & $\begin{array}{l}\text { Treated mice } \\
\left.\text { Survival rate( } 0_{0}^{\prime}\right)\end{array}$ & $\begin{array}{l}\text { Virus } \\
\text { dilution }\end{array}$ & $\begin{array}{l}\text { Control mice } \\
\text { Survival rate }(\%)\end{array}$ & $\begin{array}{c}\text { Treated mice } \\
\text { Survival rate }(0,0)\end{array}$ \\
\hline $10^{-2}$ & 0 & 35 & $10^{-2}$ & 0 & 28 \\
\hline $10^{-3}$ & 33 & 43 & $10^{-3}$ & 44 & 65 \\
\hline $10^{-4}$ & 70 & 70 & $10^{-4}$ & 77 & 83 \\
\hline
\end{tabular}

4) Curative Effect against Virus. The virus dilutions of $10^{-2}, 10^{-3}$, and $10^{-4}$ were inoculated intranasally or intravenously into groups of ten mice, and solutions of the drug were injected into the infected mice with the dose of $150 \mathrm{mg} / \mathrm{kg}$ in addition of hyaluronidase of $0.1 \mathrm{unit} / \mathrm{kg}$, intravenously twice 3 hours and 24 hours after the inoculation; and intraperitoneally 48 hours and 72 hours after the inoculation. The results are given in the Table 5 by survival rate $(\%)$.

Table 5. Curative Effect of the Drug

(1)

\begin{tabular}{|c|c|c|c|c|c|}
\hline \multicolumn{3}{|c|}{ Intranasal Infection } & \multicolumn{3}{|c|}{ Intravenous Infection } \\
\hline $\begin{array}{l}\text { Virus } \\
\text { dilution }\end{array}$ & $\begin{array}{l}\text { Control mice } \\
\text { Survival rate }(\%)\end{array}$ & $\begin{array}{c}\text { Treated mice } \\
\text { Survival rate }(0)\end{array}$ & $\begin{array}{l}\text { Virus } \\
\text { dilution }\end{array}$ & $\begin{array}{l}\text { Control mice } \\
\text { Survival rate }(0,0)\end{array}$ & $\begin{array}{c}\text { Treated mice } \\
\text { Survival rate(\%) }\end{array}$ \\
\hline $10^{-2}$ & 0 & 20 & $10^{-2}$ & 0 & 36 \\
\hline $10^{-3}$ & 28 & 68 & $10^{-3}$ & $\ldots$ & 75 \\
\hline $10^{- \pm}$ & 50 & 83 & $10^{-4}$ & 22 & 70 \\
\hline
\end{tabular}

It is made clear from the Table that the drug possessed a remarkable curative effect on the virus by intranasal and intravenous routes. The virus dilutions of $10^{-2}$ were inoculated intranasally into groups of ten mice, and solutions of the drug were injected into the infected mice with the doses of $10-150 \mathrm{mg} / \mathrm{kg}$, once 3 hours after the inoculations, or twice 3 hours and 24 hours after the inoculation. The results are given in the Table 6 by survival rate $(\%)$.

Table 6. Curative Effect of the Drug (2)

Drug Dose $(\mathrm{mg} / \mathrm{kg})$

\begin{tabular}{lrrrrrr}
\hline Administration of the Drug & 150 & 100 & 75 & 50 & 25 & 10 \\
\hline Once 3 hours after the Inoculation & 75 & 50 & 40 & 20 & 25 & 0 \\
Twice 3 and 24 hours after the Inoculation & 80 & 60 & 40 & 25 & 20 & 0 \\
Control - & 0 & & & & & \\
\hline
\end{tabular}

It is shown from the Table that a single dose or double of $100-150 \mathrm{mg}$ $\mathrm{drug} / \mathrm{kg}$ each exerted a marked curative effect. 
The virus dilutions of $10^{-2}$ were inoculated intranasally into groups of ten mice, and at various intervals after the inoculation solutions of the drug were injected intravenously into the infected mice with the dose of $100 \mathrm{mg} / \mathrm{kg}$ or $150 \mathrm{mg} / \mathrm{kg}$. The results are given in the Table 7 by survival rate (\%).

It is shown from the Table that a single dose of $100 \mathrm{mg} \mathrm{drug} / \mathrm{kg}$ exerted a marked effect within 12 hours after the inoculation, and a single dose of $150 \mathrm{mg} \mathrm{drug} / \mathrm{kg}$, within 24 hours after the inoculation.

Table 7. Curative Effect of the Drug (3)

\begin{tabular}{lrrrrrrrrrr}
\hline \multicolumn{10}{c}{ Interval after the Inoculation of the Virus (hours) } \\
\hline Drug & 0 & 5 & 6 & 12 & 24 & 36 & 48 & 60 & 72 \\
\hline Dose $(\mathrm{mg} / \mathrm{kg})$ & 0 & 0 & & & & & & & & \\
Control & 58 & 44 & 42 & 45 & 37 & 33 & 22 & 20 & 14 \\
100 & 67 & 67 & 55 & 45 & 45 & 28 & 27 & 33 & 23 \\
150 & 67 &
\end{tabular}

\section{DISCUSSION}

It is well known that chemoprophylactic and chemotherapeutic effects with small neurotropic viruses have been hardly observed. And it has been, also, found by us that newer drugs aureomycin as well as terramycin, chloramphenicol and phenosulfazol did not exert any effect on Encephalitis japonica.

The compound R, 2-3532/1 which has been recently published by $R$. J. Schnitzer et $\mathrm{al}^{(6)}$, possesses only a limited effect on Col. SK-virus and MM-virus.

Sodium 3-phenylazonaphthionate was selected as the most effective from many compounds which were tested with Encephalitis japonica. The observations with this compound as described in the experimental part show that this compound possesses a remarkable effect on such a neurotropic virus as Encephalities japonica in vitro and in vivo with a low toxity. These facts may be, also, found in the infection with Poliomyelitis anterior (Further works with this virus is in progress).

The antiviral activity of the compound might be caused by direct interaction between the compound and the virus, since the virus was inactivated immediately after the exposure of the virus to the compound.

The chemoprophylactic effect of the compound was observed; the effect was more marked by the intravenous administration than the intranasal. It may be, therefore, assumed that the compound might exert more marked effect on the human infection. with the virus, since the human infection with the virus would be caused by a far milder process than artificial infection. 
The chemotherapeutic effect was observed, even at comparatively longer interval after the infection with the virus. The effect was more marked by the intravenous administration than intranasal. The satisfactory curative effect may be obtained in mice with one or two $1.00-150 \mathrm{mg} / \mathrm{kg}$ doses.

The milder the process of infection was and the more direct the route of injection, the more marked the effect might be.

As discussed above, it may be concluded that sodium 3-phenylazonaphthionate is of promise for the clinical use. Clinical experiment have been carried out in the Komagome Hospital (Tokyo) and the Momoyoma Hospital (Osaka), the results obtained will be soon published on the Clinical Journals of Japan.

Further works on this problem is in progress.

\section{SUMMARY}

(1) Sodium 3-phenylazonaphthionate shows a remarkable effect on the Japanese encephalitis virus in vitro and in vivo. Sodium 3-phenylazonaphthionate possesses virucidal, protective and curative effects against the neurotropic virus and has a low toxity.

(2) It is assumed that the antiviral activity of sodium 3-phenylazonaphthionate might be caused by direct interaction of the compound and the virus.

(3) Sodium 3-phenylazonaphthionate is of promise for treatments of diseases caused by small neurotropic viruses,

\section{REFERENCES}

1. T. Ueda, S. Toyoshima and T. Wachi: J. Pharmaceut. Soc. of Japan, 72:No. 2 (1952).

2. S. D. Kramer et al: J. Immunol., 49:273 (1944).

3. W. C. Cutting et al: J. Immunol., 57:379 (1947).

4. H. G. Wood and I. I. Rusoff: J. Exp. Med., 82:297 (1945).

5. T. Ueda, S. Toyoshima and T. Wachi: ibid.

6. R. J. Schnitzer et al: Proc. Soc. Exp. Biol. \& Med., 69:182 (1951). 